\title{
Interactive Effects of Common Haplotypes of Two Leukocyte Diapedesis-Related Genes, LFA-1 and JAM-A on Breast Cancer Risk
}

\author{
Bengu TOKAT ${ }^{1}$, Tulin OZTURK ${ }^{2}$, M. Fatih SEYHAN ${ }^{1}$, Zerrin CALAY ${ }^{2}$, Sennur ILVAN ${ }^{2}$, \\ Mete B. TUZUNER ${ }^{1}$, Oguz OZTURK ${ }^{1}$, Hulya YILMAZ-AYDOGAN ${ }^{1}$ \\ ${ }^{1}$ Istanbul University, Aziz Sancar Institute of Experimental Medicine, Department of Molecular Medicine \\ ${ }^{2}$ Istanbul University, Cerrahpasa Medical School, Department of Pathology, Istanbul, TURKEY
}

\begin{abstract}
Leukocyte diapedesis is an important process in breast cancer etiopathogenesis. Therefore, Junctional adhesion molecule-A (JAMA) and lymphocyte function-associated antigen-1 (LFA-1) genes are among potential candidate genes involved in breast cancer development. In the present study, JAM-A rs790056 (T>C), LFA-1 rs8058823 (A>G) and LFA-1 rs2230433 (C>G) gene variations and their associations with breast cancer risk were investigated in breast cancer patients and healthy subjects. The JAM-A and LFA1 genotypes were determined in 108 breast cancer patients and 63 healthy controls with Polymerase Chain Reaction- Restriction Fragment Length Polymorphism (PCR-RFLP) assay. LFA-1 rs8058823 common AA genotype $\left(\chi^{2}=6.062, p=0.014\right)$ and A allele frequency $(p=0.001)$ and LFA-1 rs2230433 rare GG genotype frequency $(p=0.048)$ was higher in the patient group compared with controls. The TA haplotype (JAM-A rs790056-T, LFA-1 rs8058823-A alleles) frequency was significantly increased in the patient group compared with controls ( $p=0.0173$ ), while the TG haplotype (JAM-A rs790056-T, LFA-1 rs8058823-G alleles) and CG haplotype (LFA-1 rs2230433-C, LFA-1 rs8058823-G alleles) frequencies were significantly lower in the patient group compared with controls ( $p=$ 0.0051 and $p=0.002$, respectively). In addition, the TCG haplotype (JAM-A rs790056-T, LFA-1 rs2230433-C, LFA-1 rs8058823-G alleles) frequency was significantly lower in the patient group compared with controls $(p=0.0096)$. Haplotype analysis confirmed that the LFA-1 rs8058823 is more effective in breast cancer risk than LFA-1 rs2230433 and JAM-A rs790056. LFA-1 rs8058823 A allele may be related to breast cancer risk, influencing leukocyte diapedesis. Our findings indicate that functional gene variations associated with leukocyte diapedesis may affect breast cancer risk.
\end{abstract}

Keywords. Breast cancer, Gene, Junctional adhesion molecule-A, Lymphocyte function-associated antigen-1, Haplotype

ÖZET

Lökosit Diapeziyle İlişkili LFA-1 ve JAM-A Genlerindeki Yaygın Haplotiplerin Meme Kanseri Riskinde İnteraktif Etkileri Lökosit diapedezi meme kanseri etyopatojenezinde önemli bir süreçtir. Bu nedenle, Bağlantı Adezyon Molekülü-A (JAM-A) ve lenfosit fonksiyon ilişkili antijen-1 (LFA-1) genleri meme kanseri gelişiminde rol oynayan potansiyel aday genler arasındadır. Bu çalışmada meme kanseri hastaları ve sağlıklı bireylerde JAM-A rs790056 (T>C), LFA-1 rs8058823 (A>G) ve LFA-1 rs2230433 (C>G) gen varyasyonlarının meme kanseri riski ile ilișkileri araștıııdı. JAM-A ve LFA-1 genotipleri 108 meme kanseri hastası ve 63 sağlkklı kontrolde polimeraz zincir reaksiyonu- Restriksiyon Fragmanı Uzunluk polimorfizmi (PZR-RFUP) teknikleri kullanılarak belirlenmiştir. Hasta grubunda kontrol grubuyla karşılaştııldığında LFA-1 rs8058823 yaygın AA genotipi $\left(\chi^{2}=6.062, p=0.014\right)$, A allel frekansı $(p=0.001)$ ve LFA-1 rs2230433 nadir GG genotip frekansı ( $p=0.048$ ) yüksektir. Hasta grubunda kontrole kıyasla TA haplotip (JAM-A rs790056-T, LFA-1 rs8058823A allelleri) frekansı anlamlı olarak yüksek gözlenirken ( $p=0.0173$ ), TG haplotip (JAM-A rs790056-T, LFA-1 rs8058823-G allelleri) ve CG haplotip (LFA-1 rs2230433-C, LFA-1 rs8058823-G allelleri) frekansları anlamlı olarak düşüktür (sırasıyla, $p=0.0051$ ve $p=0.002$ ). Ayrıca TCG haplotip (JAM-A rs790056-T, LFA-1 rs2230433-C, LFA-1 rs8058823-G allelleri) frekansı hasta grubunda kontrole göre anlamlı olarak düşüktür ( $p=0.0096$ ). Haplotip analizi LFA-1 rs8058823'in meme kanseri riskinin belirlenmesinde LFA-1 rs2230433 ve JAM-A rs790056'den daha etkili olduğunu doğrulamaktadır. LFA-1 rs8058823 A alleli lökosit diapedezini etkileyerek meme kanser riski ile ilişkili olabilir. Bulgularımı lökosit diapedezi ile ilişkili fonksiyonel gen varyasyonlarının meme kanseri riskini etkileyebileceğine işaret etmektedir.

Anahtar Kelimeler: Meme kanseri, Lökosit Bağlantı Adezyon Molekülü-A, lenfosit fonksiyon ilişkili antijen-1, Haplotip 


\section{INTRODUCTION}

Breast cancer is the most frequently diagnosed cancer and the leading cause of cancer related deaths among females worldwide. ${ }^{1}$ Extravasation of cancer cells involves rolling, adhesion and transmigration (diapedesis) that are similar to extravasation of leukocytes (transendothelial migration, leukocyte diapedesis). ${ }^{2}$ Junctional adhesion molecule-A (JAM-A), also known as F11R, JAM-1, or CD321, is a type I transmembrane immunoglobulin G glycoprotein, which is expressed at epithelial cells tight junctions and intercellular borders of endothelial cells, and also on the surface of platelets and some leukocytes. ${ }^{3}$ JAM-A has important functions including intercellular junction assembly and cell polarity ${ }^{4}$, cell morphology ${ }^{5}$, angiogenesis ${ }^{6}$, and leukocyte migration. ${ }^{7}$

The effect of JAM-A expression on risk of breast cancer remains controversial. Many studies have suggested a positive correlation between JAM-A and progression, migration, and invasion of breast cancer. ${ }^{8-10}$ However, some studies yielded conflicting results. ${ }^{11,12}$

JAM-A is expressed at lower levels and limited mainly to areas of epithelial cell-cell contact in normal breast tissue ${ }^{13}$ and has been shown to be overexpressed in breast cancer. ${ }^{8}$ Moreover, JAM-A promotes cell migration in breast cancer via downstream effects on $\beta 1$-integrin activation. Adhesion of natural killer cells to the target cells/tumor cells following the stimulation by activating receptors is mediated by leukocyte integrin LFA-1, resulting in apoptosis of the target cells/tumor cells. A higher percentage of LFA-1+ breast tumor cells was observed in patients with better outcome /without recurrence and expression of LFA-1 increased in patients with good prognosis. ${ }^{14}$ Additionally, heterophilic interaction of JAM-A and LFA-1 causes transendothelial migration of leukocytes which is also a process involved in tumor cell extravasation. $^{7}$

To date, there have been a limited number of studies investigating associations of variations of LFA-1 gene with development of breast cancer. It was suggested that the LFA-1 gene variations may predict the sporadic infiltrative duct breast carcinoma risk and prognosis factors in Chinese
Han women. ${ }^{15}$ Because both of JAM-A and LFA-1 interfere with leukocyte diapedesis, they may be potential candidate genes involved in the development of breast cancer. However, there was no study investigating JAM-A gene variation alone and together with LFA-1 gene variations in breast cancer patients. Therefore, we aimed to investigate not only the distribution of the JAM-A and LFA-1 genes variants among patients with breast cancer and controls, but also the possible amplified effects of these genetic variations together on the development risk of breast cancer.

\section{PATIENTS and METHODS}

\section{Study Population}

The patient group consisted of 108 breast cancer patients with median age 50.84 \pm 12.69 years, who were admitted to Breast Services at the Department of Surgery, Cerrahpasa Medical School of Istanbul University. In addition, 63 healthy women, presenting a mean age of $51.83 \pm 5.37$ years, were used as a control group. The control group consisted of age- and sex-matched healthy subjects, subjects with a personal or family history of any cancer and chronic diseases such as cardiovascular or cerebrovascular disease, diabetes mellitus, hypertension, or renal disease were excluded from the study. Control subjects were not taking any regular medication during the study. Informed consent was obtained from all participants. All of our breast cancer patients had previously undergone appropriate surgery. Questionnaires, medical records, and pathological reports were used to confirm the diagnosis and cancer status.

All procedures performed in studies involving human participants were in accordance with the ethical standards of the institutional and/or national research committee and with the 1964 Helsinki declaration and its later amendments or comparable ethical standards. This study protocol was approved by the Local Ethical Committee at Istanbul University.

\section{Immunohistochemical Analysis of Breast Can- cer Samples}

The estrogen receptor (ER) and progesteron receptor (PR) status of the patients was defined by immunohistochemistry on formalin-fixed, paraffin- 
embedded sections of clinical specimens as part of routine pathological interpretation. Immunohistochemistry was performed using a rabbit monoclonal antihuman ER antibody (clone SP1; Thermo-Scientific, MA, USA) and a polyclonal rabbit antihuman PR antibody (clone 16, Novocastra, Leica Microsystem, Wetzlar, Germany). Nuclear staining of $>10 \%$ of cells were accepted as positive for ER or PR status.

\section{Genotyping}

Peripheral blood samples were collected in tubes containing EDTA, and genomic DNA samples were extracted from whole blood with salting out procedure. Polymerase chain reaction- restriction fragment length polymorphism (PCR-RFLP) protocols slightly modified from $\mathrm{Fu}$ et al. ${ }^{15}$ were performed to detect rs8058823 (in 3'-untranslated region (3'-UTR A>G) and rs2230433 variations (in exon 21 (2120 G>C) (Arg707Thr)) of the LFA-1 gene, while rs790056 variation (in intron $6 \mathrm{~T}>\mathrm{C}$ ) of the JAM-A gene was detected according to an PCR-RFLP method developed in our laboratory and primers used to amplify this gene region were designed according to Ensembl genome database using Primer3 program (forward 5'-GCAGTACAAAGGAGAGCCTCT-3' and reverse 5'-TGGGACACCCATGACTTCA-3').

\section{Statistical Analysis}

Statistical analysis was performed using SPSS software for Windows, version 21.0 (SPSS Inc. Chicago, USA). Allele frequencies were calculated by using gene counting method. The difference in the occurrence of the genotypes in the case and control groups was evaluated with chi-square test. In order to determine the relative risks, odds ratios and $95 \%$ confidence intervals were used. Haploview program was used for haplotype analysis ${ }^{16}$ and $\mathrm{p}$ value less than 0.05 was considered to be statistically significant.

\section{RESULTS}

\section{Clinical Investigation}

Almost half of the patient group consisted of premenopausal women and the other half was postmenopausal women. The positive expression rates of ER and PR among patients were $69.7 \%$ and $51.3 \%$ and histological grade proportions of clinical stages 1-2 and 3 among patients were $56.5 \%$ and $43.5 \%$, respectively. Lymphatic vascular and perineural invasion were present in $45.3 \%$ and $31.4 \%$ of the patients, respectively and $55.4 \%$ of tumors were positive for c-erb expression. Moreover, $87.3 \%$ had invasive ductal carcinoma, while the rest had other subtypes of breast carcinoma. There was no significant difference in mean age between patients and control subjects $(50.84 \pm 12.69$ vs. $51.83 \pm 5.37, \mathrm{p}=0.495$ ).

\section{Distributions of the JAM-A and LFA-1 Genotypes}

JAM-A rs790056 genotypes and allele frequencies were similar between the study groups $(p>0.05)$. LFA-1 rs8058823 normal AA genotype $\left(\chi^{2}=6.062\right.$, $\mathrm{p}=0.014)$ and A allele frequency $(\mathrm{p}=0.001)$ and LFA-1 rs2230433 rare GG genotype frequency ( $\mathrm{p}=$ 0.048 ) were found to be higher in the patient group compared with controls. In the patient group 21 subjects were heterozygous for the LFA-1 rs8058823 rare $G$ allele (AG), but none were homozygous for this allele (GG). In the control group, 47 subjects were heterozygous for the LFA-1 rs2230433 rare G allele (GC), but none were homozygous for this allele (GG) (Table 1). As such, statistical evaluation of data was performed on LFA-1 rs8058823 AG and LFA-1 rs2230433 GC heterozygous genotypes for subsequent analysis.

\section{Haplotype Analysis}

It was also analyzed JAM-A rs790056, LFA-1 rs2230433 and LFA-1 rs8058823 haplotypes for association with breast cancer as sets of two and three alleles together. The haplotype analysis with two alleles confirmed the association of JAM-A and LFA-1 gene variations with breast cancer and revealed that the TA haplotype (JAM-A rs790056 $\mathrm{T}$ and LFA-1 rs8058823 A alleles) frequency was significantly increased in the patient group as compared with controls $(\mathrm{p}=0.0173)$, while the TG haplotype (JAM-A rs790056 T and LFA-1 rs8058823 $\mathrm{G}$ alleles) and CG haplotype (LFA-1 rs2230433 $\mathrm{C}$ and LFA-1 rs8058823 $\mathrm{G}$ alleles) frequencies were significantly lower in the patient group as 
International Journal of Hematology and Oncology

Table 1. Distributions of JAM-A and LFA-1 genotypes in the study groups

\begin{tabular}{|c|c|c|}
\hline & \multicolumn{2}{|c|}{ Groups } \\
\hline & Control $(n=63)$ & Patient $(n=108)$ \\
\hline \multicolumn{3}{|c|}{ JAM-A rs790056 Genotypes } \\
\hline$\pi$ & 39 (61.9\%) & 69 (63.9\%) \\
\hline $\mathrm{CC}$ & $8(12.7 \%)$ & $9(8.3 \%)$ \\
\hline TC & 16 (25.4\%) & 30 (27.8\%) \\
\hline \multicolumn{3}{|c|}{ JAM-A rs790056 Alleles } \\
\hline $\mathrm{T}$ & $94(74.60 \%)$ & 168 (77.78\%) \\
\hline C & 32 (25.40\%) & 48 (22.22\%) \\
\hline \multicolumn{3}{|c|}{ LFA-1 rs8058823 Genotypes } \\
\hline AA & $40(63.5 \%)$ & $87(80.6 \%)^{*}$ \\
\hline GG & 7 (11.1\%) & - \\
\hline$A G$ & $16(25.4 \%)$ & 21 (19.4\%) \\
\hline \multicolumn{3}{|c|}{ LFA-1 rs8058823 Alleles } \\
\hline A & 96 (76.19\%) & $195(90.28 \%)$ ** \\
\hline G & 30 (23.81\%) & 21 (9.72\%) \\
\hline \multicolumn{3}{|c|}{ LFA-1 rs2230433 Genotypes } \\
\hline $\mathrm{CC}$ & $16(25.4 \%)$ & $21(19.4 \%)$ \\
\hline GG & - & $7(6.5 \%)^{* * \star}$ \\
\hline GC & 47 (74.6\%) & $80(74.1 \%)$ \\
\hline \multicolumn{3}{|c|}{ LFA-1 rs2230433 Alleles } \\
\hline C & 79 (62.70\%) & $122(56.48 \%)$ \\
\hline$G$ & 47 (37.30\%) & $94(43.52 \%)$ \\
\hline
\end{tabular}

compared with controls $(p=0.0051$ and $p=0.002$, respectively). Haplotype analysis confirmed that the LFA-1 rs8058823 A allele is the most effective in breast cancer risk and its detrimental effect on breast cancer kept in presence of JAM-A rs790056 $\mathrm{T}$ allele (Table 2).
The haplotype analysis with triple alleles (JAMA rs790056 - LFA-1 rs2230433 and LFA-1 rs8058823) revealed that the TCG haplotype (JAM-A rs790056 T- LFA-1 rs2230433 C and LFA-1 rs8058823 $\mathrm{G}$ alleles) frequency was significantly lower in the patient group compared with controls $(\mathrm{p}=0.0096)$ (Table 3$)$.

\begin{tabular}{|c|c|c|c|c|c|}
\hline \multirow[b]{2}{*}{ Haplotype } & \multicolumn{5}{|c|}{ Frequencies } \\
\hline & Overall & Patient & Control & Chi square & $\mathbf{p}$ \\
\hline \multicolumn{6}{|c|}{ JAM-A rs790056- and LFA-1 rs8058823 } \\
\hline TA & 0.666 & 0.713 & 0.587 & 5.667 & 0.0173 \\
\hline $\mathrm{CA}$ & 0.182 & 0.185 & 0.175 & 0.058 & 0.8095 \\
\hline $\mathrm{TG}$ & 0.100 & 0.065 & 0.159 & 7.847 & 0.0051 \\
\hline CG & 0.052 & 0.037 & 0.079 & 2.852 & 0.0913 \\
\hline \multicolumn{6}{|c|}{ JAM-A rs790056 and LFA-1 rs2230433 } \\
\hline $\mathrm{TC}$ & 0.441 & 0.437 & 0.448 & 0.04 & 0.8405 \\
\hline TG & 0.325 & 0.341 & 0.298 & 0.669 & 0.4134 \\
\hline $\mathrm{CC}$ & 0.147 & 0.128 & 0.179 & 4.652 & 0.1986 \\
\hline CG & 0.087 & 0.094 & 0.075 & 0.369 & 0.5435 \\
\hline \multicolumn{6}{|c|}{ LFA-1 rs2230433 and LFA-1 rs8058823 } \\
\hline $\mathrm{CA}$ & 0.462 & 0.482 & 0.429 & 0.896 & 0.3439 \\
\hline GA & 0.386 & 0.417 & 0.333 & 2.332 & 0.1267 \\
\hline CG & 0.126 & 0.083 & 0.198 & 9.59 & 0.002 \\
\hline GG & 0.026 & 0.019 & 0.040 & 1.389 & 0.2386 \\
\hline
\end{tabular}




\begin{tabular}{|c|c|c|c|c|c|}
\hline \multirow[b]{2}{*}{$\begin{array}{l}\text { Haplotype } \\
\text { (JAM-A rs790056- LFA-1 } \\
\text { rs2230433- LFA-1 rs8058823) }\end{array}$} & \multicolumn{5}{|c|}{ Frequencies } \\
\hline & Overall & Patient & Control & Chi square & $p$ \\
\hline TCA & 0.352 & 0.377 & 0.311 & 1.511 & 0.2189 \\
\hline TGA & 0.313 & 0.336 & 0.274 & 1.391 & 0.2383 \\
\hline CCA & 0.109 & 0.104 & 0.116 & 0.128 & 0.7207 \\
\hline TCG & 0.091 & 0.060 & 0.144 & 6.711 & 0.0096 \\
\hline CGA & 0.074 & 0.082 & 0.060 & 0.54 & 0.4622 \\
\hline $\mathrm{CCG}$ & 0.036 & 0.024 & 0.056 & 2.365 & 0.1241 \\
\hline CGG & 0.016 & 0.012 & 0.021 & 0.406 & 0.524 \\
\hline
\end{tabular}

\section{DISCUSSION}

The present study is the first to investigate JAM-A gene variation alone and together with LFA-1 gene variations in breast cancer patients. Several studies demonstrated the roles of JAM-A in carcinogenesis, such as being involved in signaling events inducing breast cancer cell migration via activation of Rap1 GTPase and $\beta 1$-integrin. ${ }^{9}$ Transforming growth factor- $\beta 1$ has been shown to induce breast cancer cell invasion through the downregulation of JAM-A expression. ${ }^{12}$ Also, microRNA-145 reduces breast cancer cells migration and invasion by targeting JAM-A. ${ }^{17}$ In another study, microRNA-495 induced breast cancer cell progression by repressing JAM-A . ${ }^{11}$ It was observed that JAM-A was mainly overexpressed on breast, lung and kidney tumor tissues and injections of anti-JAM-A antibody in vivo resulted in a significant tumor growth inhibition of xenograft human tumors. ${ }^{18}$ Overexpression of JAM-A in non-small cell lung cancer was correlated with tumor progression and knockdown of JAM-A resulted in G1 cell cycle arrest and growth inhibition of lung cancer cells. ${ }^{19}$ Inactivation of JAM-A reduced pancreatic tumor development by increasing antitumor immune response via promoting dendritic cell and $\mathrm{T}$ lymphocyte infiltration in pancreatic carcinoma. ${ }^{20}$ Loss of the tight junction plaque molecule zonula occludens-1 (zo1 ), that associates with the cytoplasmic domain of JAM-A, has been found to be correlated with poor prognosis in breast cancer. ${ }^{8}$ Gutwein et al. reported that JAM-A was downregulated in tumor samples of patients with renal cell carcinoma and the downregulation of JAM-A in renal cell carcinoma led to a disassembly of tight junction and to the loss of cell-cell contacts promoting the migration of tumor cells. ${ }^{21}$ It was also reported that low expression of JAM-A is significantly associated with metastasis and poor clinical outcome in pancreatic cancer ${ }^{22}$ and JAM-A expression was found to be negatively correlated with histologic grade, myometrial invasion, and stage in endometrial carcinoma. ${ }^{23}$ Moreover, low JAM-A expression was significantly associated with tumor size, lymphatic vessel invasion, lymph node metastasis, TNM stage, and poor survival in gastric cancer patients and promoted cell migration and invasion. ${ }^{24}$

Recently, it was shown that the silencing of JAMA protein expression in breast cancer cells significantly reduces breast cancer cell adhesion and migration ${ }^{9}$ due to JAM-A functions in promoting epithelial cell spreading ${ }^{5}$ and leukocyte migration. ${ }^{7}$ It has been also shown that signaling events resulting with high JAM-A expression may promote the migration of breast tumor cells associated with tumor invasion and metastasis. ${ }^{8}$ In addition, downregulation of JAM-A reduces breast cancer progression by increasing cell apoptosis. ${ }^{10}$ However, it was found that JAM-A expression was decreased in breast cancer tissues and was inversely correlated with the mobility of breast cancer cells ${ }^{11}$, it was also reported an inverse relationship between JAM-A expression in breast cancer cells and their invasive ability. ${ }^{12}$ 
Binding of lymphocyte function-associated antigen-1 (LFA-1) to the membrane-proximal domain 2 of JAM-A destabilizes the homophilic JAM-A interaction allowing leukocyte transendothelial migration. ${ }^{25}$ LFA- 1 also called $\alpha \mathrm{L} \beta 2$ integrin, CD11a/ CD18 or ITGAL, is a $\alpha \beta$ heterodimeric transmembrane glycoprotein expressed on the surface of leukocytes. ${ }^{26}$ The expression of LFA-1 in breast cancer cell line can result in the transendothelial migration of breast cancer cells. ${ }^{27}$ Likewise, it was observed that the LFA-1 participates in the immunological synapse between $\mathrm{T}$ cells and antigen presenting cells in $\mathrm{T}$ cell activation. ${ }^{28}$ It was shown that the LFA-1 engagement at the immune synapse between cytotoxic $\mathrm{T}$ cells and tumor cells is required for cytotoxic immune synapse maturation, resulting in synaptic release of both cytokines and lytic granules and, by that, in tumor cell lysis. Moreover, LFA-1 is important for natural killer cell cytotoxicity as it mediates natural killer-cell binding to intercellular adhesion molecule-1 (ICAM-1) on target cells, producing activating signals that lead to polarization of the actin cytoskeleton and cytotoxic granules followed by perforin and granzymes exocytosis. ${ }^{14}$

Considering the roles of JAM-A and LFA-1 in cancer, it is remarkable to analyze JAM-A and LFA-1 genes variations alone and together in breast cancer. In a study including 537 Chinese Han female infiltrative duct breast carcinoma patients and 577 age-matched Chinese Han healthy women, it was found that the LFA- 1 rs8058823 and LFA1 rs2230433 single nucleotide polymorphisms (SNPs) were related to infiltrative duct breast carcinoma. ${ }^{15}$

Mechanistically, 3'-UTR gene region can regulate gene expression and mediate stability, degradation and subcellular localization of $\mathrm{mRNA}^{29}$, the rs8058823 SNP located in the $3^{\prime}$ UTR was investigated and it was suggested that this variation may affect LFA-1 expression. ${ }^{15}$ Similarly, the rs2230433 variant of LFA-1 gene resulting in the amino acid substitution from arginine to threonine, is located within the integrin-alpha- 2 domain of the LFA-1 gene, which forms interactions with EGF2, FG-GAP, and Integrin- $\beta$-tail domains. Thus, the rs $2230433 \mathrm{SNP}$ is predicted to be involved in splicing regulation. ${ }^{15}$ Also, the rs790056 SNP of the
JAM-A gene is an intronic variation. Intronic variations can cause a blockage of translation and decrease in the expression of protein ${ }^{30}$ since sequence variations occurring in exons or introns may affect the correct processivity of the mRNA by disrupting the splice site or altering the secondary structure of the mRNA. ${ }^{31}$ Therefore, in this study, we investigated the potential effects of JAM-A and LFA-1 gene variations together on breast cancer development risk and their protective effects against breast cancer for the first time.

It was suggested that the LFA-1 rs8058823 AA genotype $(\mathrm{p}=0.00000418)$ and A allele $(\mathrm{p}=$ $0.00000267)$ may be protective against infiltrative duct breast carcinoma and rs8058823 AG genotype may increase infiltrative duct breast carcinoma risk $(\mathrm{p}=0.00000747) .{ }^{15}$ Concurrently, they reported that the LFA-1 rs2230433 GG genotype ( $\mathrm{p}=$ $0.0316)$ and $\mathrm{G}$ allele $(\mathrm{p}=0.0480)$ may be protective against infiltrative duct breast carcinoma and rs2230433 CG genotype may increase infiltrative duct breast carcinoma risk $(\mathrm{p}=0.0397)$. Contrary, in the present study, it was observed that both LFA$1 \mathrm{rs} 8058823$ normal AA genotype $(\mathrm{p}=0.014)$ and A allele frequency $(\mathrm{p}=0.001)$ and LFA-1 rs2230433 rare GG genotype $(\mathrm{p}=0.048)$ may be related to risk of breast cancer in a Turkish population.

In the present study, the frequency of LFA-1 rs8058823 rare $G$ allele in control and patient groups were $23.81 \%$ and $9.72 \%$, respectively. The frequency of the LFA-1 rs2230433 rare G allele was seen $37.3 \%$ in controls versus $43.52 \%$ in breast cancer patients. The frequency of rs 8058823 rare $\mathrm{G}$ allele is substantially higher than that reported in Han Chinese (Controls: 0.09\%, patients with sporadic infiltrative duct breast carcinoma: $2.14 \%)^{15}$, South Asian and European populations, but is similar to the African populations (12.0\%) (Ensembl genome database, population genetics). In contrast, the frequency of LFA-1 rs $2230433 \mathrm{G}$ allele is much lower than the reported frequency in European (70.0\%), African (58.0\%) (Ensembl genome database, population genetics), and Han Chinese population (Controls: $83.22 \%$, patients with sporadic infiltrative duct breast carcinoma: $79.94 \%),{ }^{15}$ yet is similar to the frequency of $29 \%$ in South Asian (Ensembl genome database, population genetics). The differences in frequencies of 
the LFA-1 rs8058823 and rs2230433 among study populations may reflect the importance of different ethnic origin, environmental background or other factors.

We also evaluated effects of JAM-A and LFA1 genotypes on risk of breast cancer with haplotype analysis. The haplotype results suggested that JAM-A rs790056 T allele and LFA-1 rs8058823 A allele together increase breast cancer risk. However, JAM-A rs790056 T and LFA-1 rs8058823 $\mathrm{G}$ alleles together and LFA-1 rs2230433 C and LFA-1 rs $8058823 \mathrm{G}$ alleles together reduce breast cancer risk. In the absence of LFA-1 rs8058823 A allele, JAM-A rs790056 T allele when combined with other LFA-1 alleles (LFA-1 rs2230433 C and LFA-1 rs8058823 G alleles) exhibits protective effect against breast cancer. Haplotype analysis confirmed that the LFA-1 rs8058823 was observed more effective in breast cancer risk than LFA-1 rs2230433 and JAM-A rs790056. In conclusion, findings of this study suggest that the LFA-1 and JAM-A gene variations may be useful for predicting breast cancer risk.

The main limitation in the present report is relatively small study population. Moreover, because of lacking JAM-A and LFA-1 expressions in this study, our hypothesis needs to be clarified. Therefore, future studies are needed to be conducted with greater sample size and addition of large number of SNP markers in LFA-1 and JAM-A genes, which effect JAM-A and LFA-1 expressions and leukocyte migration for breast cancer progression.

\section{Acknowledgments}

The present work was supported by a grant from the Scientific Research Projects Coordination Unit of Istanbul University (Project No: 4325).

\section{REFERENCES}

1. Torre LA, Bray F, Siegel RL, et al. Global cancer statistics, 2012. CA Cancer J Clin 65: 87-108, 2015.

2. Strell C, Entschladen F. Extravasation of leukocytes in comparison to tumor cells. Cell Commun Signal 6: 10, 2008.

3. Martin-Padura I, Lostaglio S, Schneemann M, et al. Junctional adhesion molecule, a novel member of the immunoglobulin superfamily that distributes at intercellular junctions and modulates monocyte transmigration. J Cell Biol 142: 117-127, 1998.

4. Liang TW, DeMarco RA, Mrsny RJ, et al. Characterization of huJAM: evidence for involvement in cell-cell contact and tight junction regulation. Am J Physiol Cell Physiol 279: C17331743, 2000.

5. Mandell KJ, Babbin BA, Nusrat A, Parkos CA. Junctional adhesion molecule 1 regulates epithelial cell morphology through effects on beta1 integrins and Rap1 activity. J Biol Chem 280: 11665-11674, 2005.

6. Cooke VG, Naik MU, Naik UP. Fibroblast growth factor-2 failed to induce angiogenesis in junctional adhesion molecule-A-deficient mice. Arterioscler Thromb Vasc Biol 26: 2005-2011, 2006.

7. Ostermann G, Weber KS, Zernecke A, Schroder A, Weber C. JAM-1 is a ligand of the beta (2) integrin LFA-1 involved in transendothelial migration of leukocytes. Nat Immunol 3: 151-158, 2002.

8. McSherry EA, McGee SF, Jirstrom K, et al. JAM-A expression positively correlates with poor prognosis in breast cancer patients. Int J Cancer 125: 1343-1351, 2009.

9. McSherry EA, Brennan K, Hudson L, Hill AD, Hopkins AM. Breast cancer cell migration is regulated through junctional adhesion molecule-A-mediated activation of Rap1 GTPase. Breast Cancer Res 13: R31, 2011.

10. Murakami M, Giampietro C, Giannotta M, et al. Abrogation of junctional adhesion molecule-A expression induces cell apoptosis and reduces breast cancer progression. PLoS One 6: e21242, 2011.

11. Cao M, Nie W, Li J, et al. MicroRNA-495 induces breast cancer cell migration by targeting JAM-A. Protein Cell 5: 862872, 2014.

12. Wang $Y$, Lui $W Y$. Transforming growth factor- $\beta 1$ attenuates junctional adhesion molecule-A and contributes to breast cancer cell invasion. Eur J Cancer 48: 3475-3487, 2012.

13. Brennan K, McSherry EA, Hudson L, et al. Junctional adhesion molecule-A is co-expressed with HER2 in breast tumors and acts as a novel regulator of HER2 protein degradation and signaling. Oncogene 32: 2799-2804, 2013.

14. Ascierto ML, Idowu MO, Zhao Y, et al. Molecular signatures mostly associated with NK cells are predictive of relapse free survival in breast cancer patients. J Transl Med 11: 145, 2013.

15. Fu Z, Jiao M, Zhang M, et al. LFA-1 gene polymorphisms are associated with the sporadic infiltrative duct breast carcinoma in Chinese Han women of Heilongjiang Province. Breast Cancer Res Treat 127: 265-271, 2011.

16. Barret JC, Fry B, Maller J, Daly MJ. Haploview: analysis and visualization of $L D$ and haplotype maps. Bioinformatics 21: 263-265, 2005. 
17. Götte M, Mohr C, Koo CY, et al. miR-145-dependent targeting of junctional adhesion molecule $\mathrm{A}$ and modulation of fascin expression are associated with reduced breast cancer cell motility and invasiveness. Oncogene 29: 6569-6580, 2010.

18. Goetsch L, Haeuw JF, Beau-Larvor C, et al. A novel role for junctional adhesion molecule-A in tumor proliferation: modulation by an anti-JAM-A monoclonal antibody. Int J Cancer 132: 1463-1474, 2013.

19. Zhang M, Luo W, Huang B, et al. Overexpression of JAM-A in non-small cell lung cancer correlates with tumor progression. PLoS One 8: e79173, 2013.

20. Murakami M, Francavilla C, Torselli I, et al. Inactivation of junctional adhesion molecule-A enhances antitumoral immune response by promoting dendritic cell and T lymphocyte infiltration. Cancer Res 70: 1759-1765, 2010.

21. Gutwein P, Schramme A, Voss B, et al. Downregulation of junctional adhesion molecule-A is involved in the progression of clear cell renal cell carcinoma. Biochem Biophys Res Commun 380: 387-391, 2009.

22. Fong D, Spizzo G, Mitterer M, et al. Low expression of junctional adhesion molecule $A$ is associated with metastasis and poor survival in pancreatic cancer. Ann Surg Oncol 19: 4330-4336, 2012.

23. Koshiba H, Hosokawa K, Kubo A, et al. Junctional adhesion molecule A expression in human endometrial carcinoma. Int J Gynecol Cancer 19: 208-213, 2009.

24. Huang JY, Xu YY, Sun Z, et al. Low junctional adhesion molecule A expression correlates with poor prognosis in gastric cancer. J Surg Res 192: 494-502, 2014.

25. Wojcikiewicz EP, Koenen RR, Fraemohs L, et al. LFA-1 binding destabilizes the JAM-A homophilic interaction during leukocyte transmigration. Biophys J 96: 285-293, 2009.

26. Hynes RO. Integrins: versatility, modulation, and signaling in cell adhesion. Cell 69: 11-25, 1992.
27. Wang HS, Hung $\mathrm{Y}$, Su CH, et al. CD44 cross-linking induces integrin-mediated adhesion and transendothelial migration in breast cancer cell line by up-regulation of LFA-1 (alpha L beta2) and VLA-4 (alpha4-beta1). Exp Cell Res 304: 116126, 2005.

28. Hogg N, Laschinger M, Giles K, McDowall A. T-cell integrins: more than just sticking points. J Cell Sci 116: 4695-4705, 2003.

29. Chen JM, Ferec C, Cooper DN. A systematic analysis of disease-associated variants in the 3 ' regulatory regions of human protein-coding genes I: general principles and overview. Hum Genet 120: 1-21, 2006.

30. Krauss V, Pecyna M, Kurz K, Sass H. Phylogenetic mapping of intron positions: a case study of translation initiation factor elF2gamma. Mol Biol Evol 22: 74-84, 2005.

31. Baralle D, Baralle M. Splicing in action: assessing disease causing sequence changes. J Med Genet 42: 737-748, 2005.

\section{Correspondence:}

Dr. Hulya Yilmaz AYDOGAN

Istanbul Üniversitesi, Aziz Sancar Deneysel Tip

Arastirma Enstitüsü

Moleküler Tip Anabilim Dali

Vakif Gureba Caddesi

34093 Capa, ISTANBUL / TURKEY

Tel: (+90-212) 4142000

Fax: (+90-212) 5324171

e-mail: yilmazh@istanbul.edu.tr 